\title{
Tectal Tissue Grafted to the Midbrain of Newborn Rats: Effect of Donor Age on the Survival, Growth and Connectivity of Transplants
}

\author{
Bernadette T. Majda and Alan R. Harvey \\ Department of Anatomy and Human Biology, The University of Western Australia, \\ Nedlands, Perth, W.A. 6009, Australia
}

\section{SHORT ABSTRACT}

Tectal tissue from fetal (E15, E18, E20) and newborn (P0) rats was transplanted to the midbrain of newborn rats. Graft survival and size decreased with increasing donor age. Host retinal input was found in E15, E18 and E20 grafts; the specific pattern of retinal innervation was similar for all fetal donor ages.

\section{KEY WORDS}

Superior colliculus, neural transplants, donor age, cell death, retinotectal projections, target specificity.

\section{SUMMARY}

Tectal tissue was removed from rats at embryonic ages (E) E15, E18, E20 and postnatal day 0 (P0) and grafted onto the midbrain of newborn host rats. Six to 24 weeks after transplantation we examined 1) the growth characteristics of the grafts, 2) their morphology and 3) the pattern of retinal innervation of the grafted tissue. Graft survival was markedly

Reprint address:

Alan R. Harvey

Department of Anatomy and Human Biology

The University of Western Australia

Nedlands, Perth

W.A. 6009, Australia affected by donor age. Transplants from E15 and E18 donors showed a survival rate of $90 \%$ which decreased to $35 \%$ when tissue was taken from E20 animals. Only one graft could be definitively identified in the $\mathbf{P 0}$ group. The ultimate volume of the graft was inversely related to donor age; grafts taken from E15 donors grew in size and produced the largest grafts, whereas E20 grafts showed a reduction in tissue volume from the time of implantation. Host retinal input was found in surviving grafts from all fetal donor ages (E15-E20). This input was always restricted to localized areas in the grafts containing high AChE activity; these areas are believed to contain presumptive superior collicular cells from the superficial layers. Thus, in tissue taken from fetal rats, it appears that altering the donor age does not affect the selectivity with which host retinal axons grow into and innervate specific areas within tectal grafts.

\section{INTRODUCTION}

In brain graft experiments, the relationship between graft survival and donor age is established for many regions of the central nervous system (CNS). In most instances the donor tissue must be of fetal origin; both survival rate and graft size being reduced with increasing fetal donor age $/ 3,7,13,32 /$. The same is true for transplantation to the anterior eye chamber $/ 31 /$. This correlation between donor age and graft 
size and survival appears to relate to the developmental state of the tissue at the time of transplantation. Tissue taken from donors at early gestational ages (which contains many undifferentiated neuroepithelial cells) consistently results in the largest grafts due to continued proliferation and differentiation of neurons and glia post-transplantation. In older donors there are fewer dividing cells and postmitotic neurons appear to be more vulnerable to the trauma associated with the implantation procedure.

If donor age affects the ultimate size and survival of transplanted tissue, is it possible that donor age also affects other features of grafted tissue? For example, how does donor age affect the patterns of host-graft connectivity? Tectal tissue taken from E15 rat embryos (day after mating $=\mathrm{E} 0$ ) and grafted onto the midbrain of newborn hosts shows good survival and growth within the host $/ 26,27 /$. Additionally, the grafts develop morphological and histochemical features characteristic of the normal superior colliculus (SC) $/ 17,19 /$. Of particular interest are the patterns of host-graft connectivity. Many host regions project axons into the grafted tectum /15/; in particular, there is good evidence that host retinal afferents selectively innervate areas in the graft which contain their appropriate target cells $/ 16,17,26,35 /$.

In the present study we have used tectal tissue derived from donors between E15 and post-natal day 0 (P0), and grafted it onto the midbrain of newborn hosts. We wished to determine 1) how the age of the donor affected the survival and subsequent morphological and histochemical development of grafts and 2) whether or not host retinal axons retained the ability to selectively grow into their appropriate target regions within the grafted tissue. This latter issue is of interest because in normal development retinal axons first grow into the SC at E16/6,24/. Thus we wanted to know how the prior presence of specific afferents affected the subsequent differentiation and receptivity of target neurons in the transplanted neuropil.

\section{MATERIALS AND METHODS}

The animals in this study were time-mated pigmented rats (PVG/c strain). Donor tissue was removed from fetuses at gestational ages $(E) 15$, 18, 20 and from newborns (P0) (day after mating $=\mathrm{E} 0, \mathrm{P} 0=22.5)$. Tectal tissue was excised from the donor animals and implanted over the left tectum of newborn recipient animals of the same strain (for details of procedure see ref. 26). Whole or half tecta were transplanted from the E15 and E18 donors. In the older age groups $(\mathrm{E} 20, \mathrm{P} 0)$ the SC were thicker and less pliable. When tissue was obtained from these animals, small pieces $\left(0.6-0.8 \mu \mathrm{m}^{3}\right)$ were cut out from the superficial SC; no attempt was made to remove the deepest tectal laminae (stratum griseum profundum and stratum album profundum).

Six to 24 weeks after transplantation, host animals were anaesthetized with ether and both eyes injected with $2-3 \mu$ l of $30 \%$ horseradish peroxidase (HRP) (Boehringer Grade 1) in $2 \%$ dimethyl sulphoxide (DMSO). After 24 hours, the animals were deeply anaesthetized with sodium pentobarbitone (Nembutal, Abbott) and perfused transcardially with a solution of $1 \%$ sodium nitrite in $0.1 \mathrm{M}$ phosphate buffer $(\mathrm{pH} 7.4$ ) followed by a mixture of $2 \%$ glutaraldehyde and $0.4 \%$ formaldehyde in $0.1 \mathrm{M}$ phosphate buffer ( $\mathrm{pH}$ 7.4). Brains were post-fixed in the same fixative at $4^{\circ} \mathrm{C}$ for 2 hours. They were then removed, trimmed, encapsulated in albumen/gelatin (fixed with a few drops of glutaraldehyde) and left overnight in $30 \%$ sucrose in $0.1 \mathrm{M}$ phosphate buffer $(\mathrm{pH}=7.4)$. Frozen sections $(40 \mu \mathrm{m})$ were cut in the coronal plane and a 1:4 series of sections stained for HRP using the peroxidase reaction with tetramethyl benzidine (TMB, Sigma) $/ 26 /$. Parallel 1 in 4 series of adjacent sections were stained for Nissl or acetylcholinesterase (AChE) $/ 17,22 /$.

In three rats which had received E18 tectal tissue grafts, the host eyes were injected with $3 \mu 1$ of $2,3,4{ }^{3} \mathrm{H}$-Proline $(10 \mu \mathrm{Ci} / \mu \mathrm{l})(\mathrm{NEN})$ rather than HRP. These animals were perfused 24 
hours later with $4 \%$ phosphate buffered paraformaldehyde ( $\mathrm{pH}$ 7.4). Brains were embedded in egg yolk, sunk in $30 \%$ sucrose, cut frozen at $26 \mu \mathrm{m}$ and parallel series of sections stained for AChE, neurofibrils /26/, or processed for autoradiography. The latter sections were counterstained with cresyl violet.

The final volumes of the grafts were measured from seven E15 and seven E18 animals. Additionally, volumes of patches of intense $\mathrm{AChE}$ activity in the E15 and E18 grafts were also determined. Camera lucida drawings of both the graft and the AChE rich areas within the graft were made for each section in the 1 in 4 AChE-stained series. These drawings were then traced using a digitizing system which was connected to an IBM computer giving areal measurements. Because every fourth section was measured, the total volumes of the $\mathrm{AChE}$ patches and the grafts were calculated by summing the respective areas and multiplying these values by 4 times the section thickness $(40 \mu \mathrm{m})$ and then dividing by the square of the magnification. A Student's t-test was applied in order to determine whether the relative proportion of graft neuropil occupied by AChE dense patches in E15 and E18 transplants was significantly different.

\section{RESULTS}

Results presented here were derived from the analysis of 62 host animals. Fourteen of these received E15 tectal grafts, 17 received E18 tissue, 20 received E20 grafts and 11 rats received P0 donor material. Examples of grafts from each donor age are shown in Fig. 1A-D.

Tissue transplanted from E15 and E18 donors showed good survival and growth (Fig. 1A,B), with survival rates of $93 \%$ and $94 \%$ respectively. The mean volume of E15 grafts was $12.2 \mathrm{~mm}^{3}$. The volume initially grafted into the host varied from approximately 0.2 to $0.45 \mathrm{~mm}^{3}$ depending upon whether half or whole tectae were transplanted. The final size of the grafts therefore represented, on average, a 30 to 60 fold increase in volume. Tectal tissue taken from E18 donors was between 0.5 to $0.6 \mathrm{~mm}^{3}$ at implantation. The mean volume of this tissue in the host $6-12$ weeks later was $1.5 \mathrm{~mm}^{3}$. Therefore, the grafts from E18 donors increased in volume two to three fold.

In contrast to E15 and E18 grafts, tectal tissue taken from E20 donors showed poor survival; tectal transplants were identified in only 6 of the 20 host animals (30\%) (Fig. 1C). Additionally, those grafts which survived were small, the largest graft in the E20 group having a volume of about $0.09 \mathrm{~mm}^{3}$. As the volume implanted was approximately $0.6-0.8 \mathrm{~mm}^{3}$, the final volume of the grafts was reduced from the time of implantation. Only one graft (9\%) could be unequivocally identified as transplanted tectum in the P0 group (Fig. 1D).

\section{Morphology and Connectivity}

E18 grafts showed many features which have been previously described for E15 donors $/ 17,19,26 /$. In both ages, Nissl stained material revealed the presence of neurons with cell bodies ranging in size from about 6 to $20 \mu \mathrm{m}$. The majority of neurons were of medium size (10$13 \mu \mathrm{m})$ and the largest neurons $(18-20 \mu \mathrm{m})$ had a clear multipolar appearance. Small neurons (6$10 \mu \mathrm{m})$ were scattered throughout the neuropil but were often grouped together in localized areas of the grafts (Fig. $1 \mathrm{~F}, \mathrm{H}$ ); the large multipolar neurons were absent from these regions. In $\mathrm{AChE}$-stained sections, there were localized areas containing high $\mathrm{AChE}$ reactivity (Fig. 1E,G); these areas often corresponded to regions containing small, relatively close packed cells (E15, Fig. 1 E,F; E18, Fig. 1 G,H). When quantified, the proportion of the graft displaying intense homogeneous $\mathrm{AChE}$ activity was similar in both E15 and E18 grafts. In E15 grafts, the proportion of $\mathrm{AChE}$ patch to total graft volume was about $8.5 \%$ compared with about $10 \%$ in E18 grafts. These were not significantly different. For comparison, the SGS occupies approximately $25 \%$ of the volume of the normal SC.

Grafts from both E15 and E18 donors were 

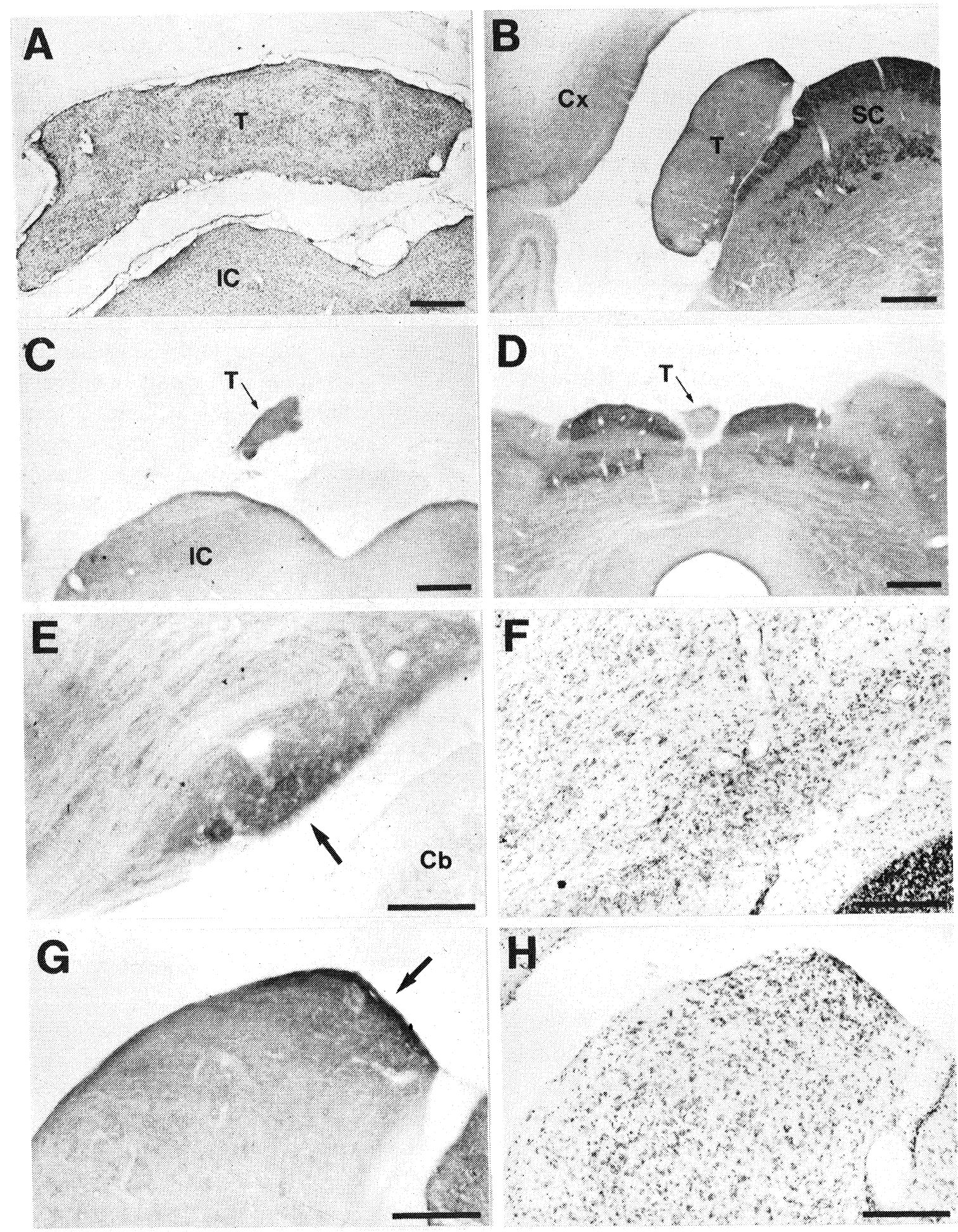

Fig. 1: A, Nissl stained section showing an E15 tectal graft $(T)$. B-D, AChE stained sections showing examples of $E 18(B), E 20(C)$ and $P 0(D)$ tectal grafts $(T)$. E-F, high power views of adjacent sections through an E15 tectal graft. The dense AChE stained area in E (arrowed) is shown in Nissl stained material (F) to contain a preponderance of small relatively close

packed cells. G-H, adjacent sections through an E18 transplant. Again note the correspondence between the AChE dense region (arrow) and cellular architecture $(H)$. IC, host inferior colliculus; SC, host superior colliculus; Cx, host cerebral cortex; $\mathrm{Cb}$, host cerebellum. Scale bars, $A-D=500 \mu \mathrm{m} ; \mathrm{E}-\mathrm{H}=$ $200 \mu \mathrm{m}$. 
innervated by host retinal axons. As described previously $/ 16,26 /$, such innervation only occurred if the transplants had fibre connections with, or were embedded within, the superficial layers of the host SC. Nine of the 13 surviving E15 grafts (69\%), and 9 of the 16 surviving E18 transplants $(56 \%)$ received host retinal input. Retinal innervation of tectal grafts was confined to localized areas lying adjacent to the surface of the transplants. These retino-recipient areas were always found to correspond to areas containing intense $\mathrm{AChE}$ activity (cf. ref. 15). Two examples of retinal innervation of E18 tectal grafts are shown in Fig. 2 B,D and adjacent AChE stained sections are shown in Fig. 2 A,C.

As with E15 and E18 grafts, in the largest E20
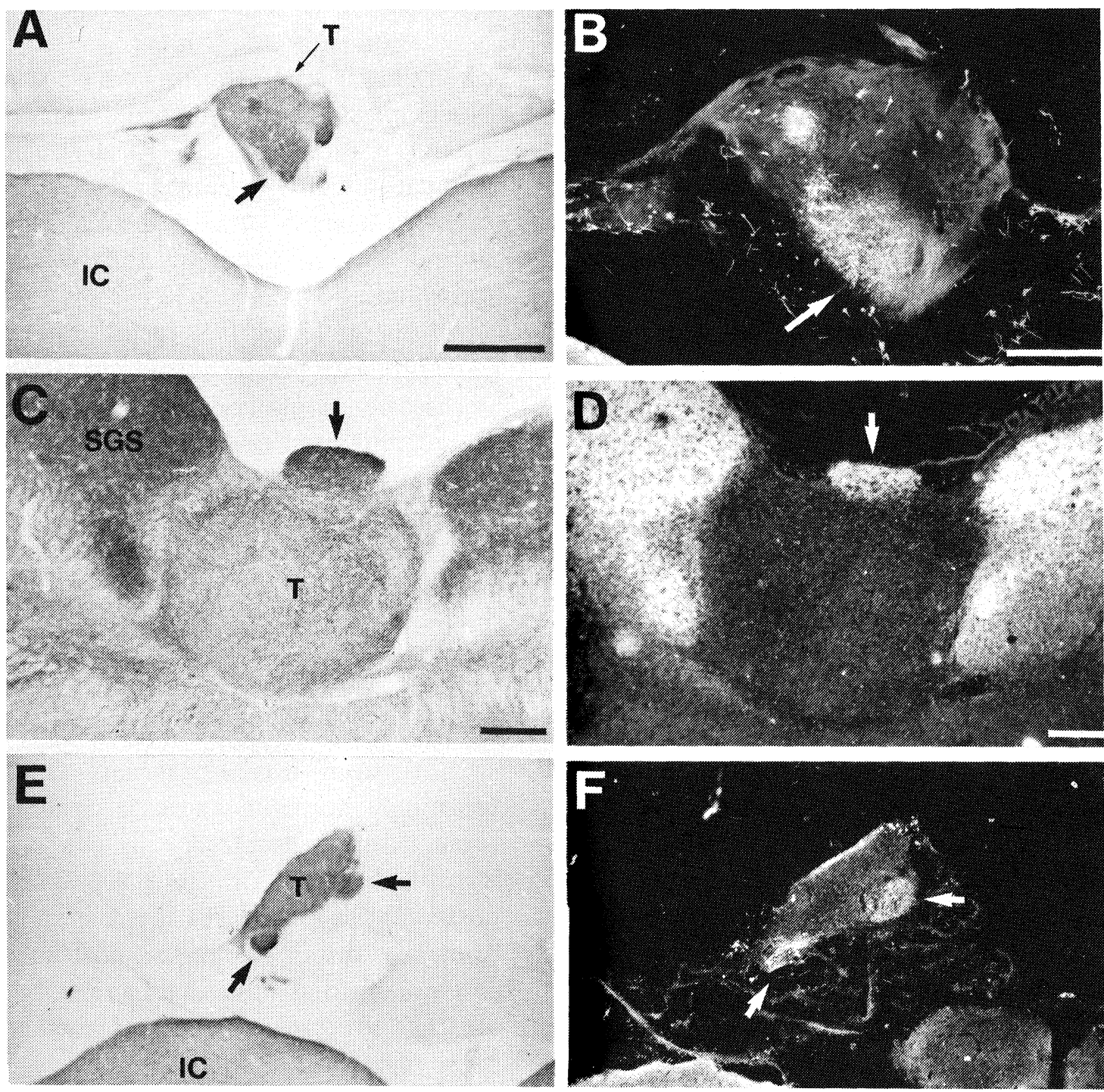

Fig. 2: $A-D, E 18$ transplants. A-B, near adjacent sections of tectal graft (T) showing AChE staining $(A)$ and host retinal input $(B)$. $B$ is a dark field photomicrograph showing HRP labelled axons in the graft. Note the correspondence between retinal input and $A C h E$ dense regions (arrows). $C-D$ as in $A-B$, except $D$ is dark field autoradiograph showing ${ }^{3} \mathrm{H}$-proline labelled retinal axons. Again note

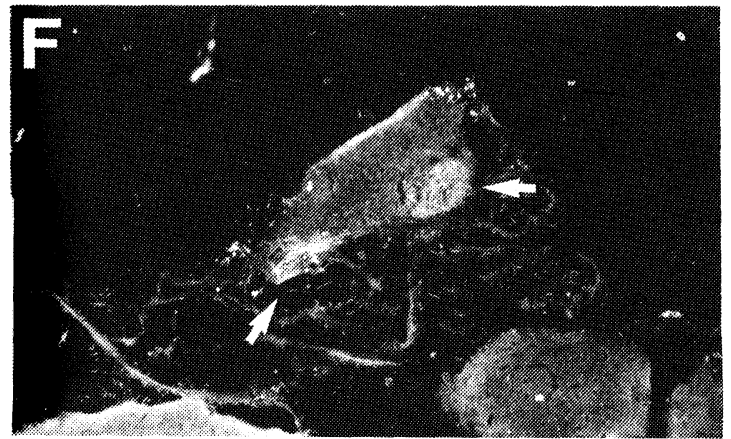

correspondence between optic input and AChE histochemistry (arrows). E-F, adjacent sections of an E20 tectal graft (T) stained for AChE (E) and reacted to show HRP labelled retinal fibres (F). Two patches of AChE and retinal input are arrowed. IC, host inferior colliculus; SGS, stratum griseum superficiale. Scale bars, $A, E=500 \mu \mathrm{m} ; B-D, F=200 \mu \mathrm{m}$. 
grafts it was possible to discern areas of intense AChE activity (Fig. 1C, Fig. 2E). Although not quantified, it appeared that a larger proportion of the graft was stained for AChE, perhaps because the initial graft tissue was mostly obtained from superficial SC (see Methods). Near adjacent Nissl stained sections showed that these AChE patches corresponded to areas which contained a predominance of small cells. Although the remainder of the graft contained a variety of neuronal cell sizes $(6-15 \mu \mathrm{m})$, the larger multipolar neurons $(18-20 \mu \mathrm{m})$ observed in E15 and E18 grafts were rarely seen. In the few surviving E20 grafts that were innervated by host retinal axons ( 5 transplants), input was restricted to the superficially located regions which stained intensely for $\mathrm{AChE}$ (Fig. 2E,F). This was similar to the pattern of retinal innervation of E15 and E18 tectal transplants. There was no identifiable retinal input to the one surviving P0 graft.

\section{DISCUSSION}

In summary we have shown that with increasing donor age, the size and survival of tectal grafts decreases. This inverse relationship of size and survival with donor age has been described in many CNS regions $/ 3,7,13,23,32 /$. It is important to consider the developmental events which have occurred at, or prior to, the removal of the donor tissue when describing the final, mature appearance of transplanted tectum. The mitotic state of tissue is an important factor. Grafts taken from E15 resulted in the largest grafts and also contained mitotically active cells at implantation; at E15, about $22 \%$ of collicular neurons are generated $/ 30 /$ and further neurogenesis occurs at E16-E17 /1,30/. Neuronal and glial cell division can also continue after transplantation $/ 21 \%$. The extensive growth of E15 grafts contrasts with the 2-3 fold increase in volume of E18 grafts. As tissue taken at this age contains almost exclusively post-mitotic neurons $11,30 /$, the post-transplantation growth of the grafts would be restricted to differ- entiation and morphological growth of neurons and proliferation and growth of glial cells.

Another factor contributing to the final size of grafts is cell death. Although cell death probably occurs at all ages in grafted tissue, the extent to which it affects the final size of the transplant is likely to be more pronounced with increasing donor age. Some possible reasons for this include 1) increased susceptibility to anoxia, perhaps due to a transient period of interrupted circulation $/ 20 /$ and to the greater density of older tissue, 2) neurons may change their biochemical and trophic requirements with age, 3) maturation of the supporting glial cell population and 4) retrograde cell death may occur as a result of axotomizing donor neurons during the removal of the tissue prior to transplantation $/ 3,13,23,32 /$.

In our material, E20 tectal grafts were small and survived poorly. However when present, grafts often contained a predominance of small to medium-sized cells; larger neurons typical of the intermediate layers (the deepest tectal layers were generally not transplanted - see Methods) were only occasionally seen. These cells are born relatively early /1,30/ and many are likely to have generated efferent axons by E20. In grafts from other CNS areas, absence of large neurons in older graft material has been interpreted as being due to axotomy and/or loss of trophic support from extrinsic targets $/ 3,5,13,32 /$. Interestingly however, there is evidence that in some cases axotomized cells can survive after transplantation. For example, cells in early postnatal hippocampus retrogradely labelled prior to excision from the host survive intracerebral grafting /36/ and it has also been suggested that axotomized cerebral cortical cells remain viable after transplantation /11/. Differences in viability may relate to differences in trophic requirements, perhaps the presence of collateral branches within the donor tissue and also the location of the graft within the host. With regard to the latter, transplantation of retina to the brain is best performed if the tissue is taken before the optic nerve is established $125,27 /$. However when the posterior (vitreal) chamber is used as the locus for transplantation, 
P1-P2 retinae, which include axotomized ganglion cells, apparently survive well /2,4,8,9/.

It is instructive to compare the growth and survival of tectal grafts from different aged donors with E15 grafts maintained in vitro for various times prior to transplantation /18/. In these experiments, E15 tecta were cultured for 3, 7 , or 14 days before being transplanted onto the midbrain of newborn hosts. Therefore tissue which spent 3 or 7 days in vitro (3DIV, 7DIV) can be considered to be of an equivalent age to $\mathrm{E} 18$ and $\mathrm{P} 0$ grafts $(\mathrm{P} 0=\mathrm{E} 22.5)$. In contrast to the E18 grafts of this study, the size of the 3DIV grafts was often comparable to that of E15 grafts which were not cultured. Similarly, there was a large difference between survival of 7DIV and P0 grafts; 7DIV grafts showed excellent survival and growth post-transplantation while there was only one surviving graft from the P0 group. There was also some survival of 14DIV transplants /18/. It therefore seems that age of tissue excision is an important factor in cell survival and therefore in the final size of tectal grafts. Similar observations have been made using retinal explants and grafts $/ 28 /$ and cerebellar explants and grafts $/ 10 /$. A period of time in vitro allows transplantation of chronologically older neurons, and their supporting glia.

A major aim of this study was to determine whether the specificity of host retinal innervation of tectal grafts was dependent upon the age of the donor tissue. In past experiments, E15 tissue was mostly used, primarily because it was "virgin" tissue, retinal axons reaching the tectum only on E16 /6,24/. In one study, it was shown that tecta from 13 to 20 day old embryos could be innervated by neurons from a wide number of host areas, but the distribution of these axons within the grafts was not determined /15/. The data from the present study show that in E18 and E20 grafts, the distribution of host retinal axons is similar to that seen in E15 transplants. In all cases the projections are limited to circumscribed regions near the graft surface that contain intense $\mathrm{AChE}$ activity. These localized areas have been shown elsewhere to be almost cer- tainly homologous to the SGS of normal SC $/ 16,17,19,26,35 /$. Thus the selective pattern of host retinal innervation of tectal grafts is retained in donor tissue from all fetal ages tested. It has been reported that the first optic synapses are seen in the SC at E17 /24/. The number is very low and does not seem to increase appreciably until at least the first postnatal week /38/. Thus while it is not possible to determine the number of synapses and their postsynaptic targets in E20 tectum, it is clear that the prior presence of optic axons in the SC does not necessarily affect the receptivity of target cells after transplantation. This is an interesting observation which may be of general relevance to the transplantation of neural tissue from, and to, other brain regions.

The status and receptivity of target cells in the CNS is, of course, an important issue in regeneration biology. Recent studies have shown that retinal axons regrowing after injury grow back to but fail, to any appreciable extent, to enter the SC in 6 day old rats $/ 12 /$. By contrast, regenerating retinal axons in 15-20 day old rats will grow into and selectively innervate specific target cells in E15 tectal grafts placed in lesion cavities /14/. Ingrowth into the host SC of these rats does occur but is sparse by comparison (cf. ref. 37). An obvious interpretation of these data is that the state of maturation of the target tissue is an important determinant of whether or not axonal ingrowth occurs. Changes likely to occur in the first few days after birth include maturation of astrocytes and oligodendrocytes 133,34/; however possible changes in the receptivity of visual target neurons themselves cannot be ruled out. An aim of future work is to use the culture and transplant techniques to determine whether such changes occur and how they might influence brain maturation and the formation and reformation of neural connections in the mammalian visual system.

\section{ACKNOWLEDGEMENTS}

We thank Dr. W.F.C. Blumer for advice on the stereological procedures. 
We are grateful to Delys Worthington and Lazlo Bubrik for technical assistance and for help with the preparation of the figures. This work was supported by a grant from the Australian NH \& MRC.

\section{REFERENCES}

1. Altman J, Bayer SA. Time of origin of neurons of the rat superior colliculus in relation to other components of the visual and visuomotor pathways. Exp Brain Res 1981; 42: 424-434.

2. Aramant R, Seiler M, Turner JE. Donor age influences on the success of retinal grafts to adult rat retina. Invest Ophthal Vis Sci 1988; 29: 498-503.

3. Björklund A, Stenevi U, Schmidt RH, Dunnett SB, Gage FH. Intracerebral grafting of neuronal cell suspensions. I. Introduction and general methods of preparation. Acta Physiol Scand Suppl 1983; 522: 918.

4. Blair JE, Turner JE. Optimum conditions for successful transplantation of immature rat retina to the lesioned adult retina. Dev Brain Res 1987; 36: 257-270.

5. Boer GJ, Gash DM, Dick L, Schluter N. Vasopressin neuron survival in neonatal Brattleboro rats; critical factors in graft development and innervation of the host brain. Neuroscience 1985; 15: 1087-1109.

6. Bunt SM, Lund RD, Land PW. Prenatal development of the optic projection in albino and hooded rats. Dev Brain Res 1983; 6: 149-168.

7. Das GD, Hallas BH, Das KG. Transplantation of brain tissue in brain of rat. I. Growth characteristics neocortical transplants from embryos of different ages. Amer J Anat 1980; 158: 135-145.

8. Del Cerro M, Gash DM, Rao GN, Notter MF, Wiegand SJ, Saith S, del Cerro C. Retinal transplants into the anterior chamber of the rat eye. Neuroscience 1987; 21: 707-723.

9. Del Cerro M, Notter MFD, Wiegand SJ, Jiang LQ, del Cerro C. Intraretinal transplantation of fluorescently labeled retinal cell suspensions. Neurosci Lett 1988; 92: 21-26.

10. Ezerman EB. Survival and development of embryonic and postnatal cerebellum transplanted onto adult rat host: effect of growth as explants in culture prior to transplantation. Dev Brain Res 1988; 41: 253-262.

11. Floeter MK, Jones EG. Transplantation of fetal postmitotic neurons to rat cortex: Survival, early pathway choices and long-term projections of outgrowing axons. Dev Brain Res 1985; 22: 19-38.

12. Gan SK, Harvey AR. Lack of ingrowth of retinal axons into the visually deafferented superior colliculus in young rats: an HRP study. Neurosci Lett 1986; 70: 10-16.

13. Gash DM, Collier TJ, Sladek JR. Neural transplantation: A review of recent developments and potential applications to the aged brain. Neurobiol of Aging 1985; 6: 131-150.

14. Harvey AR, Gan SK,. Pauken JM. Fetal tectal or cortical tissue transplanted into brachial lesion cavities in rats: Influence on the regrowth of host retinal axons. J Comp Neurol 1987; 263: 126-136.

15. Harvey AR, Lund RD. Transplantation of tectal tissue in rats. II. Distribution of host neurons which project to transplants. J Comp Neurol 1981; 202: 505520.

16. Harvey AR, Lund RD. Transplantation of tectal tissue in rats. IV. Maturation of transplants and development of host retinal projection. Dev Brain Res 1984; 12: 27-37.

17. Harvey AR, MacDonald AM. The development of acetylcholinesterase activity in normal and transplanted superior colliculus in rats. J Comp Neurol 1985; 240: 117-127.

18. Harvey AR, Rush RA, Keating PJ. Cultured fetal tectal tissue grafted to the midbrain of newborn rats: morphology of grafts and innervation by host retinal and cortical axons. Brain Res 1988; 462: 89-98.

19. Harvey AR, Warton SS. The morphology of neurons in rat tectal transplants as revealed by Golgi-Cox impregnation. Anat Embryol 1986; 174: 361-367.

20. Henschen A, Hoffer B, Olson L. Spinal cord grafts in oculo: survival, growth, histological organization and electrophysiological characteristics. Exp Brain Res 1985; 60: 38-47.

21. Jaeger $\mathrm{CB}$, Lund RD. Transplantation of embryonic occipital cortex to the brain of newborn rats: An autoradiographic study of transplant histogenesis. Exp Brain Res 1980; 40: 265-272.

22. Karnovsky MJ, Roots L. A "direct-coloring" thiocholine method for cholinesterases. J Histochem Cytochem 1964; 12: 210-221.

23. Kromer LF, Björklund A, Stenevi U. Intracephalic embryonic neural implants in the adult brain. I: Growth and mature organization of brainstem, cerebellar and hippocampal implants. J Comp Neurol 1983; 218: 433-459.

24. Lund RD, Bunt AH. Prenatal development of central optic pathways in albino rats. J Comp Neurol 1976; 165: 247-264.

25. Lund RD, Hankin MH, Sefton AJ, Perry VH. Conditions for optic axon outgrowth. Brain Behav Evol 1988; 31: 218-226.

26. Lund RD, Harvey AR. Transplantation of tectal tissue in rats. I. Organization of transplants and pattern of distribution of host afferents within them. J Comp Neurol 1981; 201: 191-209.

27. Lund RD, Hauschka SD. Transplanted neural tissue develops connections with host rat brain. Science 1976; 193: 582-584.

28. McLoon LK, McLoon SC, Lund RD. Cultured embryonic retinae transplanted to rat brain: differentiation and formation of projections to host superior colliculus. Brain Res 1981; 226: 15-31. 
29. Mesulam MM. Tetramethylbenzidine for horseradish peroxidase neurohistochemistry: A non-carcinogenic blue reaction-product with superior sensitivity for visualizing neural afferents and efferents. J Histochem Cytochem 1978; 26: 106-117.

30. Mustari MJ, Lund RD, Graubard K. Histogenesis of the superior colliculus of the albino rat: A tritiated thymidine study. Brain Res 1979; 164: 39-52.

31. Olson L, Björklund H, Hoffer BJ. Camera bulbi anterior. New vistas on a classical locus for neural tissue transplantation. In: Sladek JR, Gash DM (Eds), Neural Transplantation, Development and Function. New York: Plenum Press, 1985; pp. 125165.

32. Reier PJ, Perlow MJ, Guth L. Development of embryonic spinal cord transplants in the rat. Dev Brain Res 1983; 10: 210-219.

33. Schwab ME, Thoenen $H$. Dissociated neurons regenerate into sciatic but not optic nerve explants in culture irrespective of neurotrophic factors. J Neurosci 1985; 5: 2415-2423.
34. Smith GM, Miller RH, Silver JN. Changing role of forebrain astrocytes during development, regenerative failure and induced regeneration upon transplantation. J Comp Neurol 1986; 251: 23-43.

35. Tan MML, Harvey AR. The development and distribution of $\alpha$-bungarotoxin binding sites in rat tectal transplants. Dev Brain Res 1987; 36: 293-298.

36. T $\phi$ nder N, Gaarskjaer EB, Sunde NA, Zimmer J. Neonatal hippocampal neurons retrogradely labeled with granular blue, survive intracerebral grafting and explantation to tissue culture. Exp Brain Res 1986; 65: 213-218.

37. Vidal-Sanz M, Bray GM, Villegas-Perez MP, Thanos $\mathrm{S}$, Aguayo AJ. Axonal regeneration and synapse formation in the superior colliculus by retinal ganglion cells in the adult rat. J Neurosci 1987; 7: 2894-2909.

38. Warton SS, McCart R. Synaptogenesis in the stratum griseum superficiale of the rat superior colliculus. Synapse 1989; 3: 136-149. 

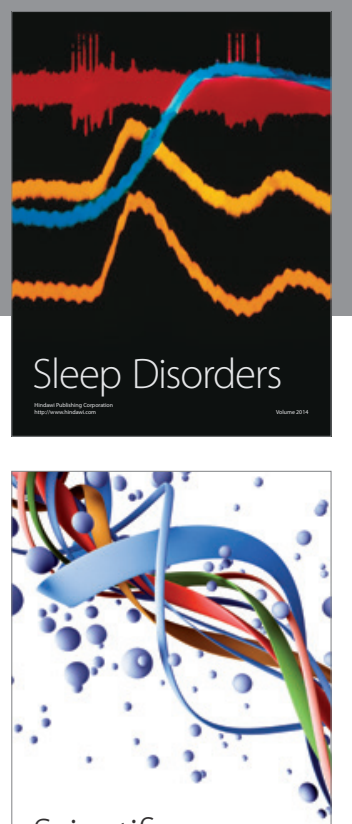

Scientifica
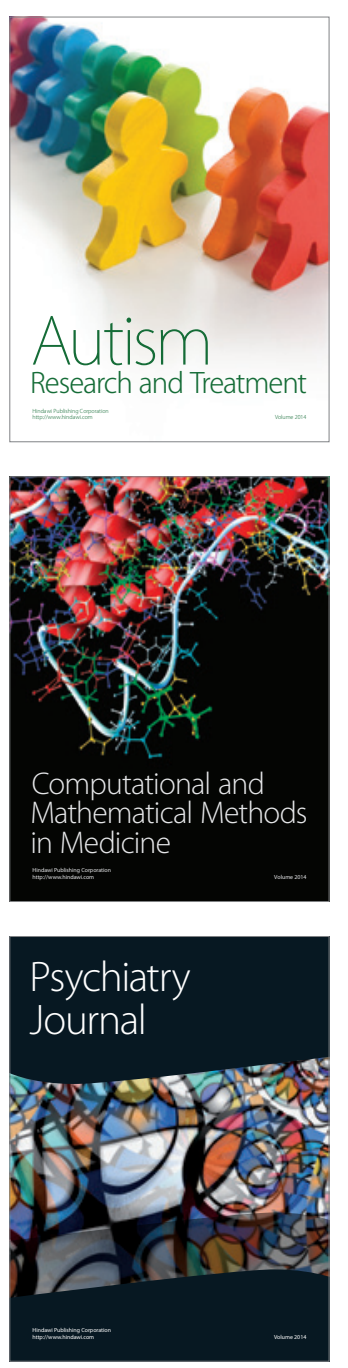
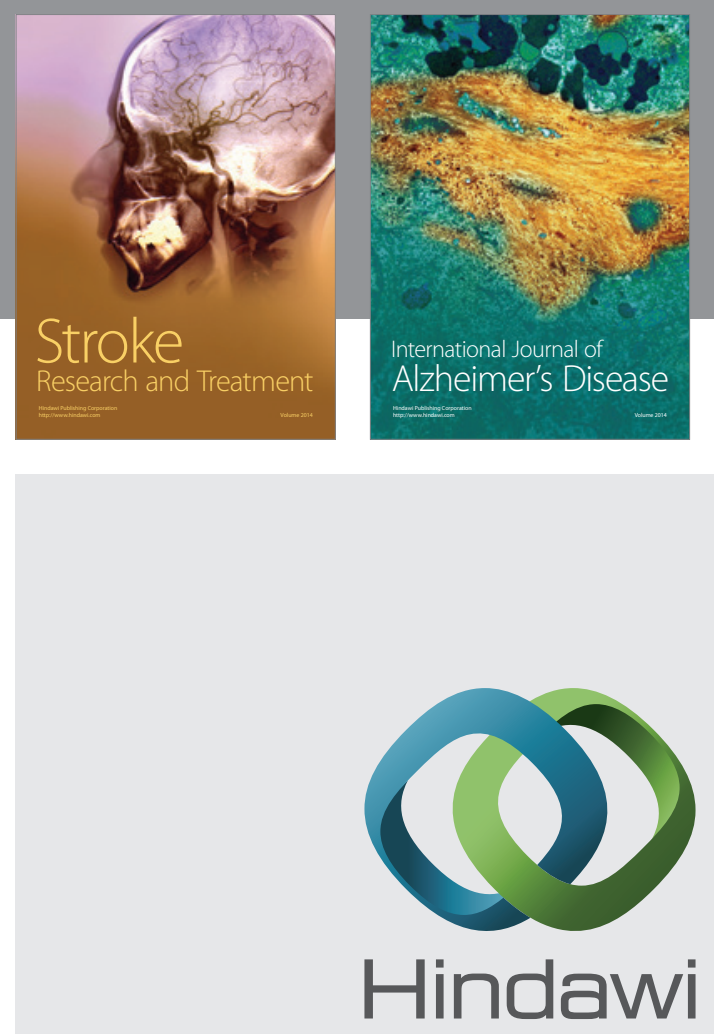

Submit your manuscripts at

http://www.hindawi.com
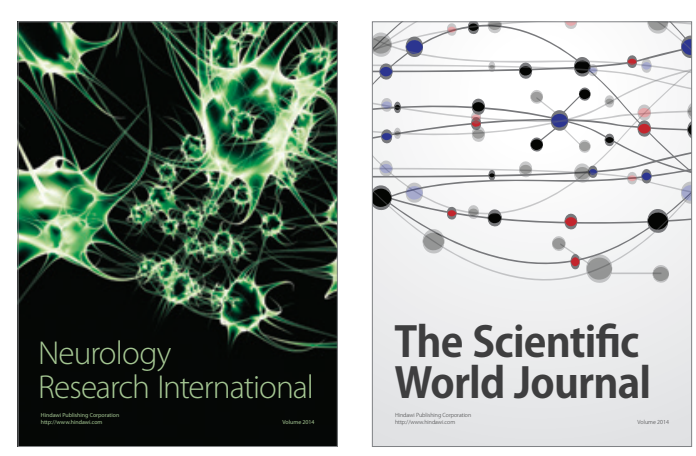

The Scientific World Journal

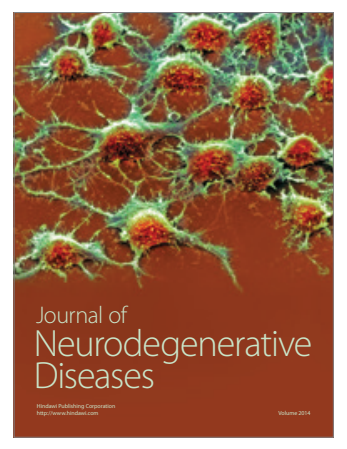

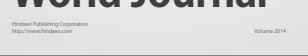

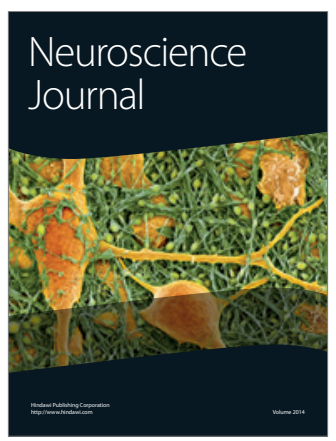

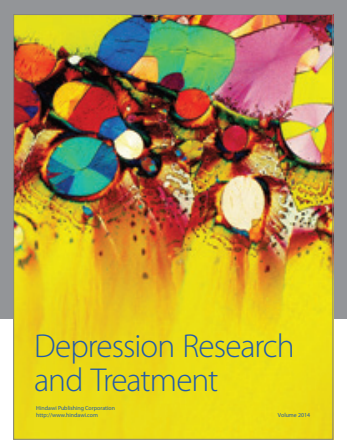
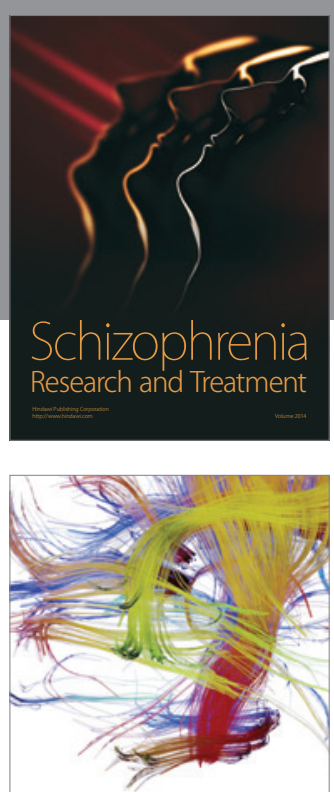

Brain Science

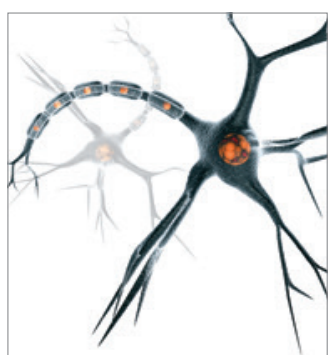

Neural Plasticity
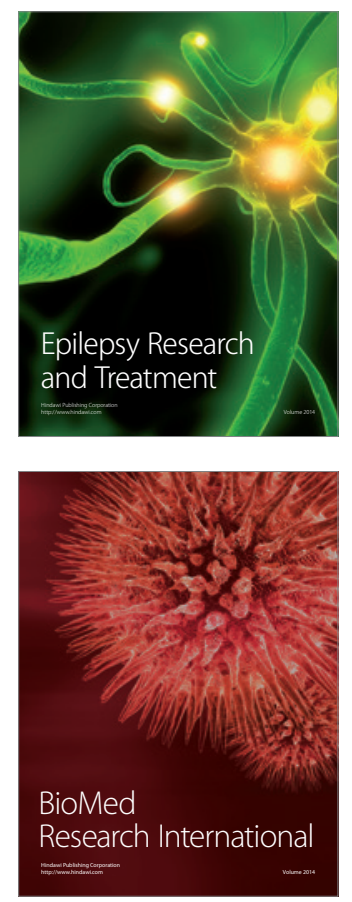

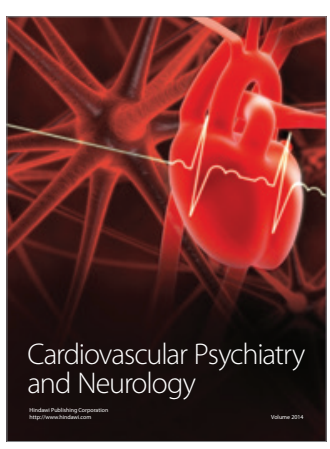

Parkinson's

Disease
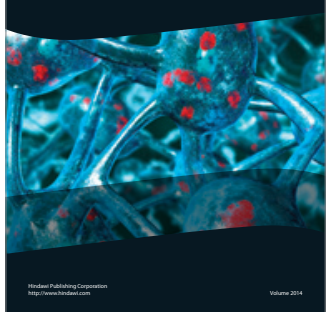